\section{全球气候变化背景下的标地修复 BROWNFIELD REMEDIATION UNDER GLOBAL CLIMATE CHANGE}

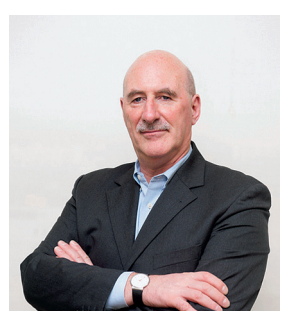

\section{尼尔・科克伍德}

哈佛大学设计研究生院景观 设计与技术专业教授、技术 与环境中心创始人和负责人

\section{Niall KIRKWOOD}

Professor of Landscape

Architecture and Technology,

Founder and Director of

and Environment, Grogy

School of Design, Graduate

University
摘要

本次采访聚焦于全球气候变化背景下的后工业区改造与棕地修 复, 以及技术在景观设计教学与实践中的应用。尽管气候变化带来 的影响多属负面, 但尼尔. 科克伍德教授认为应当从长远角度辩证 地看待这一问题。随着科学技术的迅速发展, 新时期的棕地修复项 目应运用更多的将传统技术和新技术相结合的策略, 同时鼓励更加 广泛的社区参与。此外, 基于技术在景观中应用的教学, 科克伍德 教授介绍了5 种不同类型课程的教学方法的差异。科克伍德教授亦 指出, 绝对的原创设计并不存在, 唯有不断扩充知识储备、积极参 与项目实践, 景观设计师才能够在项目设计和落地过程中更加得心 应手。

\section{关键词}

后工业区改造；棕地修复；气候变化；技术；社区参与；原创性

\section{ABSTRACT}

This interview focuses mainly on the post-industrial regeneration and brownfield remediation with the influence of global climate change and the application of technology in landscape architecture teaching and practices. Although climate change is largely regarded to be negative, Professor Niall Kirkwood suggested that we should consider its impacts dialectically in much longer time frame. With the development of science and technology, brownfield remediation in the new era should utilize new technologies with old ones and encourage extensive community participation. With regard to the teaching of technology applied in landscapes, Professor Kirkwood also introduced the differences of five types of courses. In addition, he stated that in landscape architecture design, nothing could be absolutely original. Only with a wide range of experiences and engagement in different types of projects, could landscape architects be confident in their design conception and its evolution as a material reality.

\section{KEY WORDS}

Post-Industrial Regeneration; Brownfield Remediation; Climate Change; Technology; Community Participation; Originality

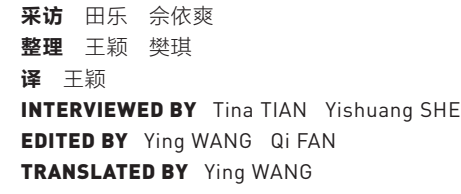


后工业区的改造和棕地修复旨在营造 更加美好的城市生活。如今, 海平面上 升、大气污染和垃圾处理不当等环境问 题日益突出, 您认为这些环境问题是否对 后工业区的改造或棕地修复提出了新的 挑战?

\section{尼尔・科克伍德（以下简称科克伍} 德）：后工业区的改造和棕地修复主要通 过改造被污染的场地来改善土地或环境的健 康状况, 其核心在于 “风险”二字一一真正 威胁人类生存的并非被污染或具有毒性的地 下结构、土壤或沉积物, 而是携带各类化学 物质的载体, 主要包括人类载体、环境载体 和动植物载体。棕地修复不仅需要去除化学 污染物, 更应当注重消除风险。因此, 在这 一过程中景观设计的介人主要是为了重塑场 地、土壤及地下结构。每当去往一个场地, 我都会尽可能地去探查地表之下的事物, 如 地下水的流动、土壤的颜色、指示性植物, 以及管道和基础设施。土壤转移是处理污染 物、移除化学物质的有效措施之一, 包括就 地 (转移至地下) 和迁地 (将土壤挖出, 转 移到其他场地或原场地中的其他位置) 两种 方式。植物修复技术则是一种就地处理方 式, 其利用不同的植物清理特定的污染物。 此外我还建议引入植被基础设施, 其可在场 地被重新利用时发挥效用。这些策略还应当 与土方工程、植物配置、野生动物的引人等 进行战略性的结合。

后工业区的改造至今已有 150 余年的历 史, 而对于层出不穷的环境问题, 我们更应
当提高警惕。在过去的100年中, 部分环境问 题已经得到了有效解决，但同时另外一些问 题却愈发严峻。单一地评价全球环境好转或 恶化都是不妥当的，我们应当将目光放得更 加长远。例如, 当谈及气候变化时, 我们时 常聚焦于其消极影响, 但全球气温升高除了 会导致城市热岛效应或荒漠化外，也能够促 成新地域的开拓, 而这些地域是当前人们所 难以涉足的, 如终年冰封雪冻的西伯利亚。 由此, 一种全新的环境类型将在俄罗斯境内 产生, 因为这里储存有大量的石油、矿石和 地下水。随着气候的变化, 未来的西伯利亚 可能越来越适宜人类居住。我们应当辩证地 看待气候变化所带来的影响, 而景观设计师 则更应当意识到其中的微妙关系。

现今, 科学技术已得到长足发展, 如 果将北杜伊斯堡景观公园这样的棕地修复 项目放在 20 年后的今天，您会有哪些创新 性的建议?

科克伍德：应用于景观设计中的工具 是一个非常有趣的话题, 其包括不同的技术 与技巧, 如河道修复、湿地建造, 以及在棕 地和后工业区改造中所运用的 “软性工程” 措施。这些技术最早出现于 20 世纪六七十年 代的建造与修复工程中, 其手法通常过于强 硬、直接, 且过于依赖化学治理手段。此外 也包括一些对于已存在近 200 年的自然技术的 创新型再应用。如今, 新技术与传统技术的 结合成为了新的发展趋势。例如, 15 16世纪 盛行于欧洲的非人工性河流修复技术, 现已
被农民应用于农田边缘斜坡的保护中。这类 不同技术之间的结合同样激发了我的灵感， 我一直在尝试将与植被相关的传统技术应用 于土壤污染物的吸收中, 如果在 20 年后的今 天再回顾北杜伊斯堡景观公园项目, 利用这 种技术修复土壤可能更为合适。

我也时常在思考如何充分利用当今最前 沿的技术, 如纳米技术、数字通讯技术等。 如果将纳米技术应用于土壤质量的监测中, 我们即可轻松获知其温度、酸碱度、湿度以 及被污染程度。此外, 随着数字通讯技术的 快速发展, 人与人之间的联系变得更加紧 密。我所感兴趣的是景观设计师如何能将这 一技术应用于自然环境中。例如, 当人们在 公园附近漫步, 即可从手机中实时获取公园 的设计者、设计理念等信息, 或在应用程序 的指引下游览公园。因此, 要想更好地将技 术应用于景观设计中, 其核心便在于探索如 何营造景观、通过何种方式运用技术, 以及 如何在社会层面积极推动技术的发展。

我们得知, 在您参与的肯尼亚基贝拉 项目中, 设计师与当地贫民窟社区展开了 密切的合作。在您看来, 社区力量在此类 景观改造项目中扮演着怎样的角色? 应该 如何将社区力量引入项目中?

科克伍德：哈佛大学设计研究生院 ( GSD ) 共有6名学生参与了肯尼亚的基贝 拉项目, 其中 5 名来自景观设计专业, 一名 来自城市规划与设计专业。起初, 学生们深 深困扰于其所做的工作仅能改变场地一时的 
境况，而很难真正影响到使用场地的居民。 不久之后, 他们提出了一个想法, 即与当地 社区协作, 共同改造场地。在此之前, 社区 居民几乎从未与景观设计师或城市设计师有 过接触, 甚至不知设计为何物。经过详细的 场地调查, 学生们发现当地存在较多未经政 府许可而建造的居所, 这些居所所处之地的 条件往往十分杂乱, 缺少供水系统、则所、 下水道等基本便利设施, 土地安全亦得不到 保障。为缓解这些问题, 学生们就基贝拉项 目提出了另一种实践方案——Kounkuey” （泰语意为依从自然），其核心在于不断聆 听、询问当地居民的需求，相互协作、反复 探索。此外, 他们还为小镇打造了垃圾收集 系统、一座公园和一个可种植和售卖蔬菜的 小型都市农场。

自2006年起，在该项目基础上组建的 Kounkuey设计倡议组织始终致力于在基贝拉 及世界其他地区开展此类项目。基贝拉项目 在景观设计中的最基本层面介人了社区的力 量, 排水系统、下水道设施、植被和社区尺 度的场地技术等都是社区参与过程中景观设 计师需重点考虑的范畴。

您在哈佛大学已有 20 余年的执教经 历, 您是如何将对于技术的理解体现在景 观教学的课程设置中的?

科克伍德：GSD的景观教学课程主要包 括5种类型: 设计课、授课式课程、研讨课 程、田野调查和研究。

设计课的核心在于反思性实践, 着重
培养学生的反思能力。在这类课程中, 教师 与学生之间存在着复杂的化学反应。一般我 们很难在设计课中向学生教授太多的技术或 技巧, 因为仅基于某一种技术便能衍生出众 多问题与实践。我坚信, 设计课能够帮助学 生明确目标, 同时激发他们的设计宏愿。因 此, 我所教授的设计课不仅包含了有组织的 实践, 更容纳了部分灵活的操作。比如, 我 很少指定学生通过某种特定的方式来进行场 地调研, 他们可根据自身的兴趣选择相应的 调研工具与方法。

而在普通的授课式课程中, 我倾向于通 过案例来让学生了解技术和技巧, 尤其是应 用于景观中的技术。例如在哈佛大学有一门 名为 “GSD 6000生态学技巧与技术” 的课 程, 它是4门连续的核心课程之一。这门课程 聚焦于如何将景观设计的理念转化为有形的 物理空间和材料, 以及如何使用轴测图、诊 断性剖面图和逆向工程图等绘图技巧提高设 计水准。

研讨课程一般以 10 名学生为一小组, 就 不同的技术类型进行探究, 探究形式包括文 献查阅和田野调查, 探究结果最终将以课堂 汇报的形式呈现。田野调查的对象主要为 建成的景观项目, 通过这一途径, 学生可 了解其建造过程等。我甚至鼓励学生在天 气恶劣时外出调查, 因为这是学习雨洪知识 的最佳时间。学生唯有在下雨天才有可能发 现场地中哪里真正会出现严重积水。而学生 的认知也将不再局限于被堵塞的排水沟, 他 们还可能了解到微型坡度和雨水流速的重 要性。

\section{您认为景观设计师是否应当更加注重 追求原创性的设计?}

科克伍德: 首先, 我认为在景观设计中 没有绝对的原创。当前的景观设计项目仍然 以下几个方面为基础: 如画美学、现代主义 与场地设计理念, 以及越来越受青睐的弹性 设计与过程驱动型设计。如果脱离了历史背 景, 任何一项设计的原创性都无从谈起。我 认为创意往往来源于知识的深厚积累与学以 致用。一些年轻教师时常要求学生作品要尽 量做到原创, 对于这一点我始终质疑。对于 景观设计师而言, 不论是对设计理念的信手 拈来, 还是将理念完美落地的自信, 都离不 开长年累月的积累。他们只有不断地行走各 地、广泛阅读、切身参与不同尺度的项目, 同时以大量的景观项目作为知识储备, 才能 更好地将所见及所学应用于自身的设计实 践中。LAF 
Post-industrial regeneration and brownfield remediation are both aimed at creating a better urban life for citizens. Nowadays, environmental problems, including sea-level rise, air pollution, and improper waste disposal, are becoming pressing issues to human' living. Do you think these problems will become new challenges to post-industrial regeneration or brownfield remediation?

\section{Niall KIRKWOOD (KIRKWOOD}

hereafter): We do post-industrial regeneration and brownfield remediation to increase the health of both the land and environment by changing sites which once were polluted and contaminated. The key word in this work is actually "risk." It is the contexts involving chemicals that threatens, rather than the pollution or toxicity in the ground, soil, or sediments. The risk of the chemicals involved in three different ways: human receptors, environmental receptors, and sometimes plants and wild life receptors. The whole brownfield work centers not only on removing chemicals, but also on removing risks. As a result, brownfield regeneration engages with landscape by shaping sites, lands, and the terrain below ground. When I go to a site, I will look for the invisible things under the ground, such as the movement of water, color of the soil, indicator plants, and pipes and infrastructure. One of the approaches to deal with pollution and chemicals is removing earth, including in-situ (means in the ground) and exsitu (means taking out and removing it to somewhere else on site or off the site). Phyto is an example of in-situ, where different planting regimes can be planted to extract the contaminants. At the same time, I will put in a vegetation infrastructure, for when the site will be reused. These strategies will be used as medium along with earth works, vegetation, and wild life in a very tactical way.

Post-industrial regeneration has been with us for about 150 years. We have to deal with environmental problems which have shifted and changed over time. Over the last 100 years, some of the environmental problems have been effectively dealt with, while some others have become worse. It is very difficult to generally conclude whether the environment of the whole globe has declined or not. I would urge us to consider in much longer time frame. For instance, although we talk about climate change in a negative way, increasing temperatures of the earth will actually not only cause the increase of the temperature in cities or desertification, but also open up land areas that are right now inaccessible, such as Siberia where there is winter almost twelve months of a year. As a result, a new type 
of environment will start to open up in Russia, because there are large deposits of oil, minerals, and subsurface water located there. As the climate changes, Siberia might become a comfortable place for people to live. I am trying to suggest we should have a balanced view of these changes. It is not black and white, and there is a subtlety that landscape architects should be conscious of

\section{Since science and technology has been greatly developed, if there were a possibility to redo brownfield remediation of the Landschaftpark project in Duisburg Nord, would there be any new idea or technique to employ?}

KIRKWOOD: The tools applied in landscape architecture is a very interesting topic. It involves technology and technique, such as the idea of "soft engineering" used in river restoration, wetlands construction, and reclamation of brownfield and post-industrial sites. These techniques were found in the construction and remediation in the 1960 s to 1970 s, which were usually hard, chemical, and fairly invasive. There are also new sets of tools called natural techniques, most of which are more than 200 years old. Currently, people are experiencing a tendency of the mixture of very new techniques and very old ones. For example, most of the stream restoration techniques developed in the 15th and 16th Century in Europe, which have been considered natural, are now used by farmers to protect slopes on field edges. This type of mixture has stimulated my interest in utilizing the old techniques of plants to uptake pollutants and contaminants in earth, which might suit the project in Duisburg Nord.

I am also looking forward to how we can make the best of the technology and technique of our present time, such as the Nano technology, and the digital and communication technologies. By introducing the Nano technology into soil, we could know the temperature, $\mathrm{pH}$, moisture, pollution levels of soils. With rapidly-developed digital and communication technologies, people are becoming closer and closer connected. What I am interested in is how landscape architects could engage in those technologies and apply them in physical environments. For example, people can walk around a garden, and get information on its designers, design ideas or guidance via their mobile phones. Thus, the challenges are actually how to make the landscape, how the technology might be utilized, and how the techniques could be advanced socially.
In the Kibera project in Kenya, local communities contributed greatly to the regeneration process. What role do you think communities could play in the practice of landscape regeneration? How can we encourage public engagement in these projects?

KIRKWOOD: With regard to the Kibera project, 6 students of GSD participated in this project, five from landscape architecture and one from urban planning and design. At the beginning, they were very unhappy as they felt their work could only perpetuate a condition, rather than affect people who use the spaces. Soon after, they proposed the idea to work in communities who had no access to landscape architects or urban designers before. They started working with local residents who at first had no idea what design was. By investigations, they found that there were many informal settlements without sanction by the government. People took land usually in very disturbed conditions to make homes and settlements, where lacked basic amenities, such as water supply, toilets, sanitation, and land security. To alleviate all these problems, the students proposed an alternative practice method to the project. They initiated an organization named "Kounkuey" (means unity with nature in Thai), whose basic 
premise was to listen, ask, collaborate, and repeat. They also developed a system of collecting waste, developing a park, and a small urban farm to grow and sell vegetables.

Since 2006, the Kounkuey Design Initiative has continued their work in Kibera and in many other regions throughout the world. The Kibera project is about community action through landscape at the most fundamental level. Landscape architecture here concerns drainage, sanitation, plants, and the introduction of community scale site technologies.

You have taught at GSD for over 20 years. How did you reflect your understanding of technology into the curriculum of landscape architecture?

KIRKWOOD: There are five types of courses in GSD: studio, lecture classes or courses, seminars, field-work, and research.

The core of a studio is reflective practice, based mainly on reaction. Studios are complex chemistries between instructors and students. It is difficult to introduce a broad range of technologies and techniques in studios, because we can set up several problems and exercises to take students through working in only one particular technique. I believe that in studios, there could be goals to achieve and certain ambitions to be addressed. Thus, in my studios I have a range of actions that are very structured and parts of which are actually much unstructured. For example, I never ask the students to investigate a site in a particular way. As a result, each of them investigates the site with their own set of interests, tools and techniques.

In course work, I tend to use case studies of technologies and techniques particularly in landscape technology, within one course as part of a set of four sequential core courses titled GSD 6000 Ecology Techniques and Technology. It concerns how to take an idea in landscape architecture into a physical reality and material reality, and how to advance design development using drawing techniques of axonometric, diagnostic sections and reverse engineering diagrams.

Seminars tend to be small groups of 10 students to research different techniques, both in literature research and field work, after which they will report back to the class. Field work means examining particularly built landscapes, where we can realize how things are made. I prefer to get students out even in bad weather, when it is the best time to study stormwater. Only when the students go out in the rain, could they be aware of what parts of the site actually flood. Leaving aside the blocked drains, they will get to know micro-grading.

\section{Do you think landscape architects} should focus on original design methods?

KIRKWOOD: First of all, in landscape architecture design there is nothing that is original. Landscape Architecture projects are still based on a couple of things: the picturesque, the ideas of modernism and site design, and the more recent concerns of resilience and process driven design. It is very difficult for someone to be original whatever that means without having concern for history. I am trying to suggest that originality comes from a strong base to build on or reconfigure. That is why I may challenge younger faculty who impose on their students need for work to be original. For landscape architects, it takes time to be confident in their command of design conception and its evolution as a material reality. They need to travel, read widely, do different forms of work from small scale to large regional projects, and to have experience of a wide range of landscapes as a bedrock of their design practice. LAF 